\title{
商業施設における照明用電力消 費量の削減に関する実験的研究 \\ EXPERIMENTAL STUDY ON THE POTENTIAL OF REDUCING ENERGY CONSUMPTION FOR LIGHTING IN COMMERCIAL FACILITIES
}

湯淺和博

藤田尚史

$* 2$

キーワード :

商業施設，照明，電力消費量，削減可能性，印象評価実験

Keywords:

Commercial facilities, Lighting, Electric consumption, Potential of reduction, Impression measurement

\section{1. はじめに}

商業施設は、民生業務部門においてエネルギー消費量の大きい建 物用途の一つであり、EDMC のエネルギー・経済統計要覧 ${ }^{1}$ によれ ば、デパート・スーパーと卸小売の合計は $21.1 \%$ を占めると報告さ れている。地球環境問題、エネルギー使用の合理化に関する法律の 改正等の影響も大きく、スーパーマーケット、コンビニエンススト ア等においても省エネルギー対策の強化が進められている。

商業施設のエネルギー消費量に関する既往研究には以下の報告等 がある。韓ら ${ }^{2)}$ は総合スーパーマーケットのエネルギー消費を実測 し、床用途別のエネルギー需要特性を分析した上で原単位作成手法 を提案している。陳ら ${ }^{3)}$ は福岡市と北九州市において店舗を含む複 数の建物用途の空調設備とエネルギー消費の実態調查を行い、空調 熱源方式、エネルギー消費原単位の特性を示している。山口ら ${ }^{4)}$ は 商業施設を業態別に分類し、業態別の一次エネルギー消費原単位の 統計的有意差を検討している。その他、スーパーマーケット、コン ビニエンスストアの省エネルギー化に向けた研究として、岩本ら ${ }^{5)}$ 、 中野ら ${ }^{6}$ 、田中 ${ }^{7)}$ 、白石ら ${ }^{8)}$ の報告がある。著者ら ${ }^{9)}$ もショッピング センターのエネルギー消費の調查を行い、照明用エネルギー消費量 は空調とともに大きいこと等を報告している。

商業施設では利用客の安全性、快適性に加え、店舗自体や商品に 対して良い印象を持たせる環境形成が重要であり、照明の果たす役 割は大きい。照明用の電力消費量の削減に関しては、商業施設を含 めて様々な建物用途で取り組みがなされており、以下の報告等があ る。望月ら ${ }^{10)}$ はオフィスにおけるタスク・アンビエント照明につい て学生被験者による評価実験を行い、行為によって好まれる照明環 境が異なること等を示している。北谷ら ${ }^{111}$ は昼光利用をしている庁 舎の竣工後の運用実態と照明用エネルギー消費量について報告して いる。三木ら ${ }^{12}$ は住宅のリビング・ダイニングを対象に多灯分散照 明の被験者評価実験を行い、照明パターンと電力消費の関係につい

\section{Kazuhiro YUASA — $* 1 \quad$ Naofumi FUJITA $-* 2$}

Commercial facility is one of the building use with much energy consumption. The aim of this paper is to clarify the reduction possibility of power consumption for lighting through subject's evaluation experiment. The method of making the environment which illuminated darkly in false using the grasses type filters was proposed, and results of basic experiments including transmittance of the filters, relationship between brightness and illumination, relationship between illumination and power consumption were shown. Students subject's evaluation experiment in supermarket was conducted and the reduction possibility of power consumption lighting was clarified.
て検討している。

著者らの既往研究 ${ }^{13)}$ ではコンビニエンスストアの照明設備に対す る経営者と利用者の意識の違いを示し、照明の明るさの低減率に関 して画像を用いた評価実験を行い、照明用電力量の削減可能性を検 討した。本研究では、実空間における照明の明るさの低減に関する 評価方法を検討し、スーパーマーケットにおける学生被験者の評価 実験を通して、照明用電力消費量の削減可能性を明らかにすること を目的としている。用いた評価方法は、光環境を検討する上で精度 は不十分ではあるが、商業施設等の実空間において実際に照明設備 を変えて実験を行うことが困難な場合に、疑似的に容易に行うため の方法として提案した基礎的段階のものである。

\section{2. 照明の明るさの評価方法に関する基礎的実験}

\section{1 実験概要}

本研究では、実空間における照明の明るさの低減を評価するため、 図 1 に示寸ような評価用フィルタを作成した。評価用フィルタ（以 下、フィルタ）は市販のメガネ型オーバーグラス（ $\mathrm{S}$ 社製）とフィ ルム（E 社液晶保護フィルム）を用い、オーバーグラス表面 ${ }^{12}$ に貼 り合わせるフィルムの枚数を $0 、 2 、 4$ 枚と変えて透過光量の異なる 3 種類を作成した。

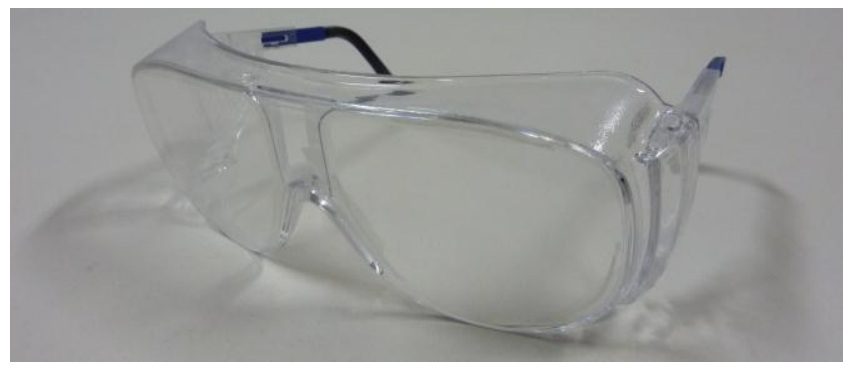

図 1 評価用フィルタ（オーバーグラスにフィルムを貼ったもの）

\footnotetext{
東京工業大学大学院理工学研究科建築学科専攻 准教授・工博 ( ( 152-8552 東京都目黒区大岡山 2-12-1)

竹中工務店 工修
Assoc. Prof., Dept. of Arch. and Build. Eng., Tokyo Institute of Technology, Dr. Eng.

Takenaka Corporation, M. Eng.
} 
次に、フィルタを通して疑似的に照明の明るさを低減した環境と、 実際に照明の明るさを低減した環境の対応を確認するために、フィ ルタの入射光量の透過率、フィルタを通して見た明るさと照度の関 係、空間の水平面照度と光源ランプの消費電力の関係に関する基礎 的実験を行うこととした。各実験の概要を表 1 に示す。なお、空間 の明るさの尺度について、本研究では照度を指標に用いて検討を行 うこととした。

\section{2 フィルタの入射光量の透過率に関する実験}

実験装置の詳細を図 2 に示す。 $450 \mathrm{~mm} \times 300 \mathrm{~mm} \times 300 \mathrm{~mm}$ の箱内 に照度計（ $\mathrm{T}$ 社一般型 $\mathrm{A}$ 級照度計）を設置し、その上部に調光型ス タンドライトを取り付けた装置を暗室に設置した。3 種類のフィルタ をそれぞれ照度計の受照面にかぶせたときの照度を測定し、基準照 度（フィルタをかぶせる前の照度）に対する割合を算出し、この值 を入射光量の透過率注2)とした。基準照度は JIS 規格の「照度基準【商 店・百貨店・その他】」14)を参考に、表 1 中に示した通り、75～3000 lx の範囲で 11 段階を設定した。なお、光源のランプには $60 \mathrm{~W}$ 型の白 熱灯を用いている。

基準照度とフィルタをかぶせた時の照度の関係を図 3 に示す。図 中のプロットは、基準照度ごとに 3 回の測定を行った平均值を示し ている。3 種類のフィルタ全てにおいて基準照度とフィルタをかぶせ た時の照度の間に高い相関関係が確認された。図中の近似直線の傾 きを各フィルタにおける入射光量の透過率とすると、オーバーグラ スのみの場合では $92.3 \%$ 、レンズ面にフィルム 2 枚を貼った場合で は $80.9 \%$ 、フィルム 4 枚を貼った場合では $71.4 \%$ となった。

\section{3 フィルタを通して見た明るさと照度に関する実験}

実験装置の詳細を図 4 に示す。前節で用いた $450 \mathrm{~mm} \times 300 \mathrm{~mm} \times$ $300 \mathrm{~mm}$ の箱にスタンドライト（白熱灯 $60 \mathrm{~W}$ 型）を取り付けたもの を2つ並べて、間についたて、側面に開口を設けた。被験者はフィ ルタを用いて箱 $\mathrm{A}$ を見た後、フィルタ無しで箱 $\mathrm{B}$ を見る。被験者に、 フィルタを通して見た箱 $\mathrm{A}$ の内部の明るさを調光によって箱 $\mathrm{B}$ に再 現してもらい、調光による水平面照度の低減率を算出した。箱 $\mathrm{A} の$ 基準照度は $500 、 1000 、 1500 \mathrm{~lx}$ の 3 段階とした。なお、被験者は 正常色覚を有する学生男女 5 名である。

各基準照度における 3 種類のフィルタの照度の低減率を図 5 に示 す。オーバーグラスのみの場合を例にすると、基準照度が $1500 \mathrm{~lx}$ の場合には被験者 5 名の平均低減率は $92 \% 、 10001 x$ では $94 \% 、 500$ $1 \mathrm{x}$ では 90 \%となり、これらの平均值は $92 \%$ となった。同様に、才 一バーグラスとフィルム 2 枚では $83 \%$ 、オーバーグラスとフィルム 4 枚では $74 \%$ となった。なお、被験者による違いとして、被験者(1) が低めの照度值を、被験者(5)゙高めの照度值を回答している等のば らつきが見られるが、低減率の平均值に対して $-5 \%$ $\%+9 \%$ 範囲 となっている。

照度の低減率は 2.2 節の透過率と比較するとやや小さいが、オー バーグラスのみの場合ではほぼ同じ、オーバーグラスとフィルム 2 枚または 4 枚の場合でも $2 \sim 3 \%$ 程度である。このことから、本実験 の設定範囲内では、フィルタを通して対象空間を側方から見た時の 鉛直面の光量の低減率は、水平面照度の低減率とほぼ同じと考えら れ、フィルタの入射光量の透過率に置き換えることが可能と判断し た。
表 1 照明の明るさの評価方法に関する基礎的実験の概要

\begin{tabular}{|c|c|}
\hline \multicolumn{2}{|r|}{ フィルタの入射光量の透過率に関する実験 } \\
\hline 手順 & 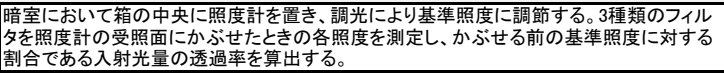 \\
\hline 基準照度 & 751x、1001x、1501x、2001x、3001x、5001x、7501x、10001x、15001x、20001x、30001xの11段階 \\
\hline \multicolumn{2}{|r|}{ フィルタを通して見た明るさと照度に関する実験 } \\
\hline 手順 & 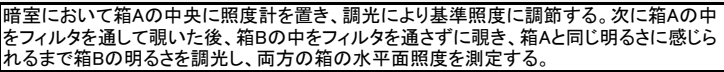 \\
\hline 基準照度 & 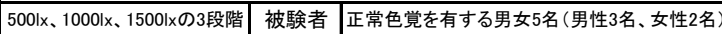 \\
\hline \multicolumn{2}{|r|}{ 空間の水平面照度とランプの消費電力に関する実験 } \\
\hline 手順 & 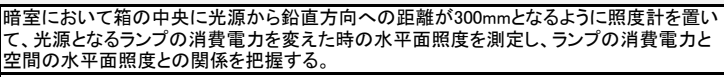 \\
\hline 使用ランプ & ランプには白熱灯を用い、消費電力は10W、20W、40W、60W、80W、100Wの6段階 \\
\hline
\end{tabular}

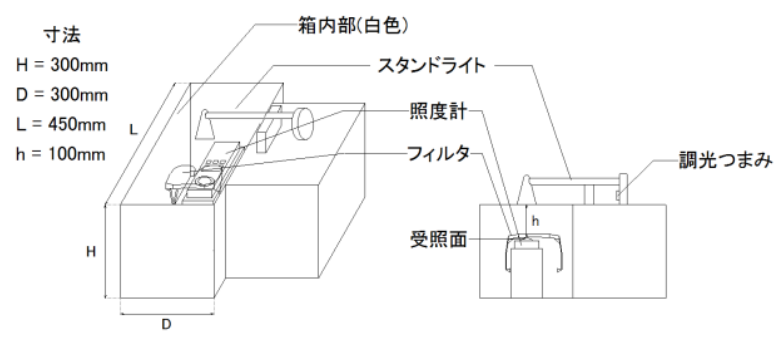

図 2 フィルタの透過率に関する実験装置詳細

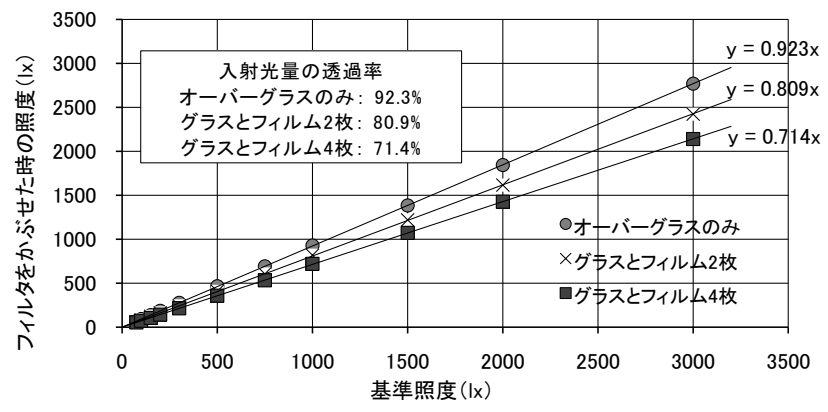

図 3 基準照度とフィルタをかぶせた時の照度の関係

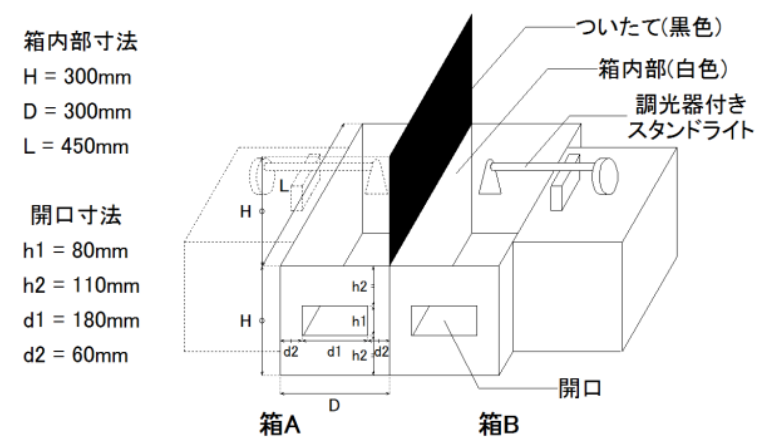

図 4 フィルタを通して見た明るさに関する実験装置詳細

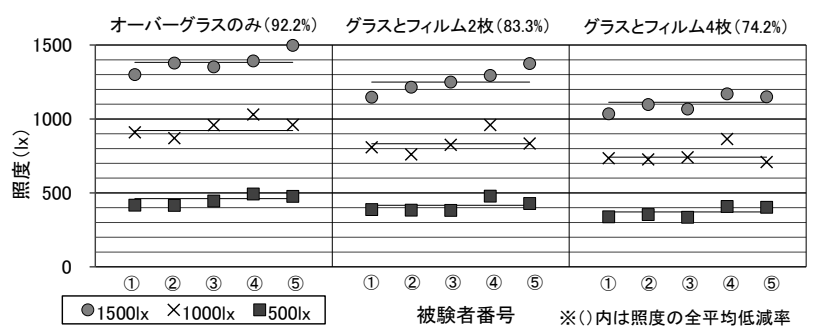

図 5 基準照度におけるフィルタの照度の低減率 


\section{4 水平面照度とランプの消費電力に関する実験}

実験装置の詳細を図 6 に示す。光源ランプの消費電力注3)を変えた 時の空間の水平面照度の変化の割合を測定する。光源ランプには 10 20、40、60、80、100 W 型の 6 種類の市販の白熱灯を用いた。また、 光源と照度計の受照面との距離は $300 \mathrm{~mm}$ とした。

ランプの消費電力と水平面照度の関係を図 7 に示す。 $60 \mathrm{~W}$ 型以下 の場合には照度值が近似直線の下側に少しずれているが、実験装置 の精度、ランプの発光効率の違い等によるものと考えられる。3 章の 印象評価実験で対象とした実店舗で使用されている光源ランプの詳 細を把握することはできていないが、100 W 型以下の範囲において、 ランプの消費電力と照度はほぼ 1 次の相関関係として扱って良いと 判断した。従って、フィルタを通して見たランプの消費電力の低減 可能割合は、水平面照度の低減割合によって、また 2.3 節の結果より 照度 500〜1500 lx の範囲ではフィルタの入射光量の透過率によって 推定可能と考えられる。

\section{3. 実空間の照明の明るさに関する印象評価実験 \\ 3.1 実験概要}

実空間を対象とした印象評価実験の概要を表 2 に、代表点水平面 照度の測定概要を表 3 に、平面略図と代表点水平面照度および商品 棚付近の水平面照度を図 8 に示す。対象とした商業施設は都内に立 地する延床面積 $1500 \mathrm{~m}^{2}$ 程度のスーパーマーケットで、出入口以外に 外光は入らない空間である。被験者は正常色覚を有する 20 代の学生 男女 20 名であり、実験は 2011 年 1 月下旬の昼間に実施した。内容 は、被験者がフィルタを装着して買い物を行い、店舗内照明の明る さについて 5 段階評価を行うもので、照明環境の「好ましさ」と買 い物行為を行うための「十分さ」を評価項目とした。具体的な実験 手順は以下の通りである。

(1)被験者はフィルタを装着した状態注4)で図 8 中のレジ付近から店舗 内全体の明るさの印象を評価する。

(2)弁当、ドリンク、生活雑貨売り場の順に、各地点で商品棚付近に 寄った時の明るさの印象、その点から見た売り場全体の明るさの 印象を評価する。

(3)手順(1) と同じ場所で、フィルタを外した状態で再度、店舗内全体 の明るさの印象を評価する。

上記(1)〜(3)を 3 種類のフィルタごとに行ったが、その際、フィルタ の装着順序は被験者ごとにランダムに変更した。また、図 8 中の各 売り場の代表点 A、B、C の照度は、それぞれ 1080 lx、818 lx、751 lx であった。

なお、実験終了後、全被験者に本実験に対する意見、感想を記述 してもらった。フィルタに関連するコメントを表 4 にまとめて示す。 透過率の減少に伴った光沢感や鮮やかさの減少があること、また、 今回の対象店舗では、透過率 $80.9 \%$ と $71.4 \%$ の差は、透過率 $92.3 \%$ と $80.9 \%$ 差ほど大きく感じられないこと等が指摘された。今後、 同様の実験を行う際の参考としたい。

\section{2 明るさの「好ましさ」と「十分さ」}

印象評価実験から得た店舗・売り場全体の明るさの「好ましさ」 に対する結果を図 9 に、「十分さ」に対する結果を図 10 に示す。基 本的にはフィルムの透過率の低下に伴い評価值が下がっているが、 「好ましさ」の生活雑貨売り場では評価值 2 の回答割合がフィルム 2 枚より 4 枚の場合に減少した。3 種類のフィルタの装着順序によって

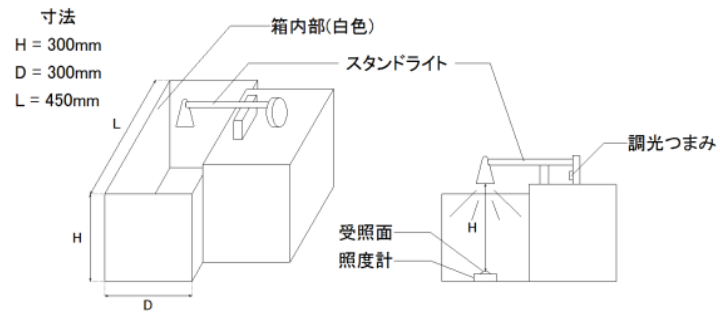

図 6 水平面照度とランプの消費電力に関する実験装置詳細

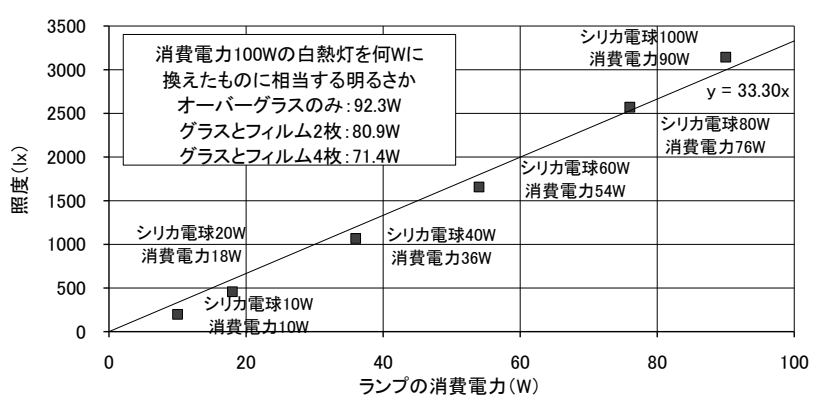

図 7 ランプの消費電力と水平面照度の関係

表 2 印象評価実験の概要

\begin{tabular}{|c|c|c|c|c|c|c|}
\hline 実験内容 & \multicolumn{6}{|c|}{\begin{tabular}{|l|} 
実店舗において、メガネ型フィルタをつけて買い物をし、店舗内の照明の明るさに対す \\
る十分さと好ましさの印象を評価し、照明用電力消費量の削減可能性を検討する。
\end{tabular}} \\
\hline 対 & \multicolumn{6}{|c|}{ 目黒区大岡山にあるスーパーマーケット1店舗 } \\
\hline 実験期間 & \multicolumn{6}{|c|}{ 2011年1月22日（土） 27日（木）10:00～15:00 } \\
\hline 回答者 & \multicolumn{6}{|c|}{ 正常色覚を有する20代の大学生20名 (男性13名、女性7名) } \\
\hline \multirow{3}{*}{ 評価項目 } & 5段階評価 & 1 & 2 & 3 & 4 & 5 \\
\hline & +分さ & 十分でない & やや十分でない & どちらでもない & やや十分である & 十分である \\
\hline & 好ましさ & 好ましくない & やや好ましくない & どちらでもない & やや好ましい & 好ましい \\
\hline 対象エリア & \multicolumn{2}{|c|}{ 店舗全体 } & \multicolumn{4}{|c|}{ 弁当・ドリンク·生活雑貨売り場 } \\
\hline フィルタの装着 & \multicolumn{2}{|c|}{ 」•「なし」の2評価 } & \multicolumn{4}{|c|}{ 「あり」の1評価 } \\
\hline 備考 & \multicolumn{6}{|c|}{ 対象エリアのうち昼光の影響を受けない地点において評価 } \\
\hline
\end{tabular}

表 3 代表点水平面照度の測定概要

\begin{tabular}{|c|c|}
\hline 測定内容 & 店舗内におけける通路と商品棚付近の代表点におけける水平面照度を測定する。 \\
\hline 対象店埔 & 目黒区大岡山にあるスーパーマーケット1店埔 \\
\hline 測定点 & $\begin{array}{c}\text { 通路は、通路の中央の床からの高さが } 900 \mathrm{~mm} \text { の地点 } \\
\text { 商品棚付近は、A、、、点の棚からら100mm離れた、床からの高さが } 900 \mathrm{~mm} \text { 点 } 1500 \mathrm{~mm} \text { の地点 }\end{array}$ \\
\hline
\end{tabular}

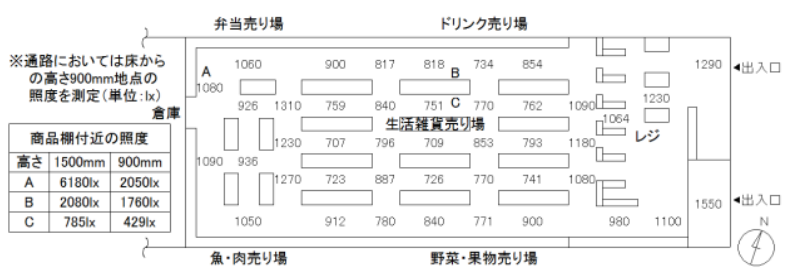

図 8 通路の代表点水平面照度および商品棚付近の水平面照度

表 4 実験終了後の被験者のコメント

\begin{tabular}{|c|c|}
\hline フィルタ & コメント内容 \\
\hline $\begin{array}{c}\text { グラスのみ } \\
\text { (透過率92.3\%) }\end{array}$ & $\begin{array}{l}\text { 裸眼、メガネ使用等、通常の見え方と変わらない。 } \\
\text { 弁当売り場では、光沢が強じられる商品がある。 }\end{array}$ \\
\hline 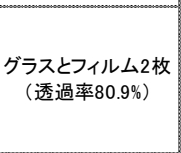 & $\begin{array}{l}\text { 裸眼、グラスのみのフィルタと比較して明らかに暗い。 } \\
\text { 店舗全体の明るさは落ち着いた感じを受ける。 } \\
\text { 遠方の売り場を見た際、天井付近を中心に暗さを感じる。 } \\
\text { 商品に対する光沢がなくない、鮮やかさが減少したように感じる。 } \\
\text { 生活雑貨売り場では、商品棚の下段が暗く、表示が読みづらい。 }\end{array}$ \\
\hline $\begin{array}{c}\text { グラスとフィルム4枚 } \\
\text { (透過率71.4\%) }\end{array}$ & $\begin{array}{l}\text { フィルム2枚の場合より少しだけ暗く感じる。 } \\
\text { 全体的に光沢、鮮やかさが感じられず、均一な感じを受ける。 } \\
\text { 商品のインパクトが落ちたように感じる。 } \\
\text { 遠方の売り場を見た際、天井付近を中心に暗さを感じる。 } \\
\text { 生活雑貨売り場では、商品棚の下段が暗く、表示が読みづらい。 } \\
\text { 照明直下の商品棚では暗さを感しないい。 }\end{array}$ \\
\hline
\end{tabular}


直前のフィルタの印象が影響したこと等が考えられ、実験手順につ いて改善すべき点と思われる。

「好ましさ」に対しては、全売り場において評価值 3～5 の回答が $85 \%$ 以上を占める結果となった。評価值 1 は無く、評価值 2 は弁当 売り場のフィルム 4 枚で $5 \%$ 、店舗全体で相対的に照度が低いドリン クと生活雑貨売り場でも $15 \%$ 以下である。一方、「十分さ」に対して は「好ましさ」より厳しい評価となった。実験終了後の被験者の感 想には、売り場によっては商品を選別する際に不自由さを感じたこ と等があり、評価值 2 の回答がドリンクと生活雑貨売り場ではフィ ルム 4 枚の場合に $30 \sim 35 \%$ 、弁当売り場でも $10 \%$ となった。しかし、 グラスのみ、フィルム 2 枚では評価值 2 は $15 \%$ 以下に留まっており、 照度低減の可能性が十分にあると考えられる。

\section{3 照明用電力消費量の削減可能性}

3.2 節において、より厳しい評価となった「十分さ」に対して、評 価値が 1 または 2 と回答した割合に基づいて閾值を設定する。例え ば、図 9 の店舗全体に打いては、閾值 $10 \%$ あ゙あばフィルム 2 枚（透 過率 $80.9 \%$ )、閾值 $30 \%$ \%あればフィルム 4 枚（同 $71.4 \%$ ）に対応 する照度まで低減可能であると判断する。

閾値を $10 、 20 、 30 \%$ とした場合の各売り場の水平面照度值を図 11 に示す。現状の照度が 1080 lxである弁当売り場では闇值によらず 771 $1 \mathrm{x}$ まで低減できる結果となり、他の売り場とは異なっている。閾値 $20 \%$ の場合でみると、弁当売り場では $1080 \mathrm{~lx}$ から $771 \mathrm{~lx}$ 、ドリンク 売り場では 818 lx から $6621 \mathrm{l}$ 、生活雑貨売り場では $751 \mathrm{~lx}$ から $608 \mathrm{~lx}$ まで低減可能となり、20３0\%の照明用電力消費量の削減に繋がる ものと判断できる。

\section{4. まとめ}

本報では、実空間の照明の明るさの低減に関する評価方法として、 オーバーグラスとフィルムによって作ったメガネ型フィルタを用い て疑似的に照明の明るさを落とした環境を作り出す方法を提案し、 その基礎的実験として、フィルタの入射光量の透過率、フィルタを 通して見た明るさと照度の関係、水平面照度と光源ランプの消費電 力の関係を把握した。また、このフィルタを用いて、スーパーマー ケット内の実空間を対象として、買い物行為を行う際の照明の明る さの「好ましさ」と「十分さ」に対する印象評価実験を行い、照明 用電力消費量の削減可能性を示した。

今回の実験方法については、光順応のコントロール、輝度の考慮 等を含めて光環境の視点から不十分な点が多く、今後、フィルタ自 体の改良とともに検討を進め、実用的な評価方法としての確立を目 指したい。また、様々な商業空間に扔ける実験を行い、統計的分析 についても検討する必要がある。

\section{注}

1)用いたオーバーグラスは眼鏡の上から装着できる十分な大きさがあり、透明 部分のほぼ全域にフィルムを貼っている。作成時には著者らがフィルタを装 着して、正面や側面からの透過光に違和感がないことを確認しているが、フ イルムを貼れていない部分の透過光が存在し評価に影響する可能性がある。 2) 使用した市販フィルムの透過率を乗じることでフィル夕の透過率は計算さ れるが、オーバーグラス自体の透過率が不明であったこともあり、実験で算 出することとした。実験装置については、箱内部の反射光がフィル夕側面か ら入り达む可能性もあり改善の余地がある。

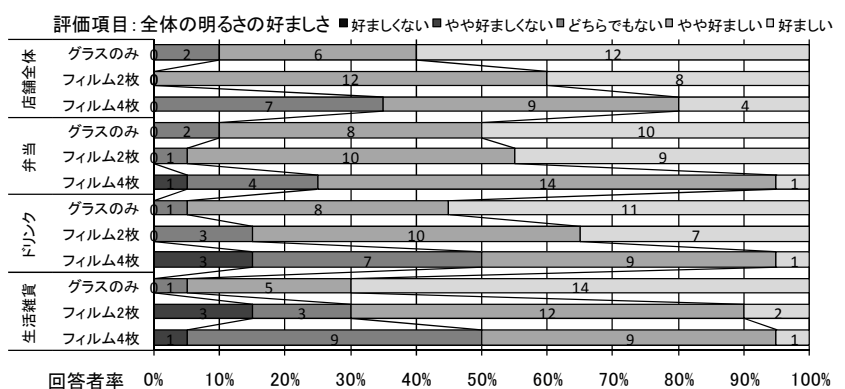

図 9 店舗・売り場全体の明るさの「好ましさ」に対する評価

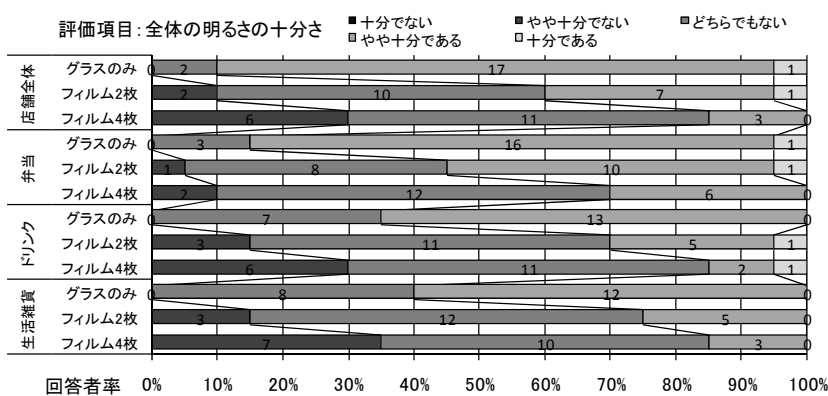

図 10 店舗・売り場全体の明るさの「十分さ」に対する評価

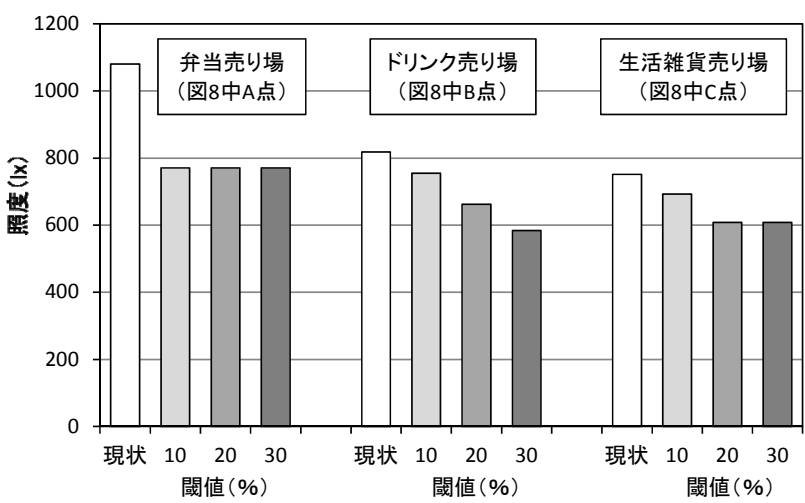

図 11 䦭値に基づく各売り場の水平面照度

3) 本実験に扔いてランプの消費電力は調光器による指示值であり、測定値では ない。図 7 の測定結果に扔ける近似直線とのずれを生じた一要因となった可 能性がある。

4)被験者は図 8 中のレジ付近でフィルタを装着し、目が慣れたのを確認した後 に評価を行った。光順応に対しては検討が不十分であり、今後、本実験方法 の確立に向けて詳細な検討が必要である。

\section{謝辞}

本研究を進めるにあたっては、印象評価実験に打いて実空間を利用させて頂 きましたスーパーマーケットの関係各位に、また、被験者として東京工業大学 の学生の方々にご協力を賜りました。ここに記して感謝の意を表します。

\section{参考文献}

1)EDMC エネルギー・経済統計要覽、日本エネルギー経済研究所 計量分析ユ ニット編、省エネルギーセンター、2011.3

2) 韓珺巧、尾島俊雄 : 床用途に基づく総合スーパーマーケットのエネルギー需 要量の予測手法に関する研究、日本建築学会環境系論文集、第 580 号、 pp.77-84、2004.6 
3) 陳超、渡辺俊行、龍有二、赤司泰義: 福岡市と北九州市における各種建物の エネルギー消費特性に関する調查研究、日本建築学会計画系論文集、第 485 号、pp.41-49、1996.7

4) 山口容平、他 14 名 : 非住宅建築物の環境関連データベースに基づく小売業 態分類別商業施設一次エネルギー消費原単位の比較、日本建築学会環境系論 文集、第 681 号、pp.889-897、2012.11

5) 岩本麻利、原英嗣、尾上佳宏、尾島俊雄 : 首都圈専門スーパーのエネルギー 消費原単位に関する研究、日本建築学会大会学術講演梗概集、D2、 pp.1259-1260、2005.9

6) 中野隆司、坂本雄三: コンビニエンスストアの省エネルギー化に関する研究、 日本建築学会大会学術講演梗概集、D2、pp.191-192、2004.8

7) 田中優里香、菊田弘輝、羽山広文 : 環境配慮型コンビニエンスストアの開発 に向けた調查研究、日本建築学会大会学術講演梗概集、D2、pp.1339-1340、 2010.9

8) 白石かおり、下田吉之、鳴海大典、村上周三、山口容平 : 低炭素社会に向け た住宅・非住宅建築におけるエネルギー削減のシナリオと政策提言、日本建
築学会大会学術講演梗概集、D1、pp.1003-1004、2010.9

9) 湯淺和博、藤井晴行 : ショッピングセンターのエネルギー消費特性に関する 実態調查、日本建築学会大会学術講演梗概集、D1、pp.853-854、2011.8

10) 望月菜穂子、宇治川正人、平手小太郎、安岡正人 : オフィスにおける行動 と好まれる照明、日本建築学会計画系論文集、第 479 号、pp.17-25、1996.1

11) 北谷幸恵、鈴木大隆、福島明 : 昼光利用建物の光環境と運用に関する実態 調査、日本建築学会技術報告集、第 21 号、pp.149-152、2005.6

12) 三木保弘、戸倉三和子、淺田秀男、松下進 : 小型高効率ランプを用いた多 灯分散照明の提案とリビング・ダイニングにおける被験者評価及び省エネル ギー性評価、日本建築学会環境系論文集、第 603 号、pp.9-16、2006.5

13) 青木俊樹、湯淺和博 : 照明設備からみたコンビニエンスストアの省エネル ギー化の可能性、日本建築学会大会学術講演梗概集、D1、pp.727-728、2008.7 14) 日本工業標準調查会 : 照度基準【商店・百貨店 一その他】, JIS Z9110

15) 本井杏奈、湯淺和博 : 夏期におけるショッピングセンターの環境に関する 調查 商業施設の環境・エネルギー消費に関する調查研究 (第 1 報)、日本 建築学会大会学術講演梗概集、D1、pp.673-674、2012.9

[2013 年 6 月 13 日原稿受理 2013 年 9 月 26 日採用決定 $]$ 